\title{
COMPLEX ETIOLOGY IN A CASE OF PULMONARY HYPERTENSION
}

\author{
Andrei Georgian Florescu, Andrei Cristian Dan Gheorghe, Cristina Elena Georgescu, \\ Alina Ștefania Luiceanu, Ioan Tiberiu Nanea, Gabriela Silvia Gheorghe \\ Clinical Hospital Professor Dr. Theodor Burghele, Bucharest
}

\section{Rezumat}

Hipertensiunea porto-pulmonară este asocierea dintre hipertensiunea portală secundară bolii hepatice sau unei etiologii extra-hepatice și hipertensiunea pulmonară. Prevalența acesteia variază între 2 și 16\% ${ }^{a}, 2^{\prime}$ și diagnosticul său necesită excluderea cauzelor alternative de hipertensiune pulmonară, lucru care poate fi uneori dificil, în special în contextul unei game largi de comorbidități pe care un pacient cu boală hepatică cronică le poate prezenta.

Prezentăm cazul unui bărbat în vârstă de 72 de ani cu un tablou clinic de insuficiență cardiacă dreaptă și semne de hipertensiune pulmonară severă obiectivate la examinarea ecocardiografică. Testele de sânge au fost pozitive pentru anticorpi anti-HCV iar imagistica prin computer tomograf a arătat semne de ciroză și hipertensiune portală. Examenele complementare și revizuirea literaturii au permis excluderea altor cauze potențiale care constituie diagnosticul diferențial al hipertensiunii pulmonare la acest pacient.

Cuvinte cheie: hipertensiune porto-pulmonară, hipertensiune pulmonară, insuficiență cardiacă dreaptă, ciroză.

\begin{abstract}
Porto-pulmonary hypertension (PPH) is the association between portal hypertension (PoH) due to liver disease or extra hepatic etiology and pulmonary hypertension (PH). It's prevalence ranges between 2 and $16 \%^{(2)}$ and it's diagnosis requires the exclusion of alternative causes of $\mathrm{PH}$ which can be sometimes challenging, especially in the context of a wide range of comorbidities that a patient with chronic liver disease can present with. We describe a 72 years-old man with a clinical presentation of right heart failure and signs of severe $\mathrm{PH}$ shown by the echocardiography. The blood tests were positive for anti-HCV antibodies and CTimaging showed signs of cirrhosis and $\mathrm{PoH}$. Complementary exams and review of the literature allowed use to rule out other potential causes constituting the differential diagnosis of the PH in this patient.
\end{abstract}

Keywords: porto-pulmonary hypertension, pulmonary hypertension, right heart failure, cirrhosis. 


\section{INTERNAL}

\section{Clinical cases}

\section{Case description}

A 72 year-old man was admitted in the cardiology department for worsening dyspnea and bilateral leg edema. He didn't smoke and had no other cardiovascular risk factors.

His medical history consisted in permanent atrial fibrillation, tuberculosis, pulmonary interstitial fibrosis, suspected chronic obstructive pulmonary disease (COPD), chronic virus $C$ hepatitis and several previous admissions in the hospital for dyspnea and leg edema. He was anticoagulated with Apixaban and had a history of previous epistaxis episodes.

The physical exam showed normal blood pressure $(120 / 80 \mathrm{mmHg}$ ), atrial fibrillation with controlled heart rate ( $62 \mathrm{bpm}), 95 \%$ oxygen saturation with no need for oxygen supplementation, bilateral leg edema, jugular turgescence, hepatojugular reflux, moderate systolic murmur on the left sternal border and at the level of the xiphoid appendix. The abdomen was mildly distended, the liver was enlarged, with firm consistency and painless.

The ECG showed atrial fibrillation, right axis deviation, complete right bundle branch block and secondary repolarization changes (Figure 1).

The chest X-ray showed cardiomegaly with broad vascular pedicles and bilateral peribronchial cuffing; bilateral apical tuberculosis sequelae (Figure 2 ).

The transthoracic echocardiography (TTE) showed preserved systolic function of the left ventricle, difficult evaluation of the diastolic function because of the atrial fibrillation and marked enlargement of the right ventricle (RV) with a basal diameter superior to the left ventricle basal diameter (Figure 3).

The right atrium (RA) was also dilated (43.4 square centimeters) (Figure 4$)$. The pulmonary artery was enlarged $(3 \mathrm{~cm}$ ) (Figure 5) and pulmonary accelerated time was short (88 $\mathrm{msec}$ ) (Figure 6). There was a flattening of the interventricular septum, a severe tricuspid regurgitation with high velocity $(3.38 \mathrm{~m} / \mathrm{s})$. The RV-RA gradient was $45.63 \mathrm{mmHg}$ (Figure 7). We noted a dilated inferior vena cava $(2.1 \mathrm{~cm})$ with less than $50 \%$ inspiratory collapse (Figure 8 ), estimated RA filling pressures at $15 \mathrm{mmHg}$ and systolic pulmonary arterial pressure (PAPs) at $60 \mathrm{mmHg}$. All of these echocardiographic criteria suggested a high probability of severe $\mathrm{PH}$, according to the ESC guidelines $^{(B)}$.

The blood tests showed anemia, no leukocytosis, mildly raised CRP, hyponatremia, mildly altered hepatic function tests with raised spontaneous INR, low total cholesterol and the presence of 


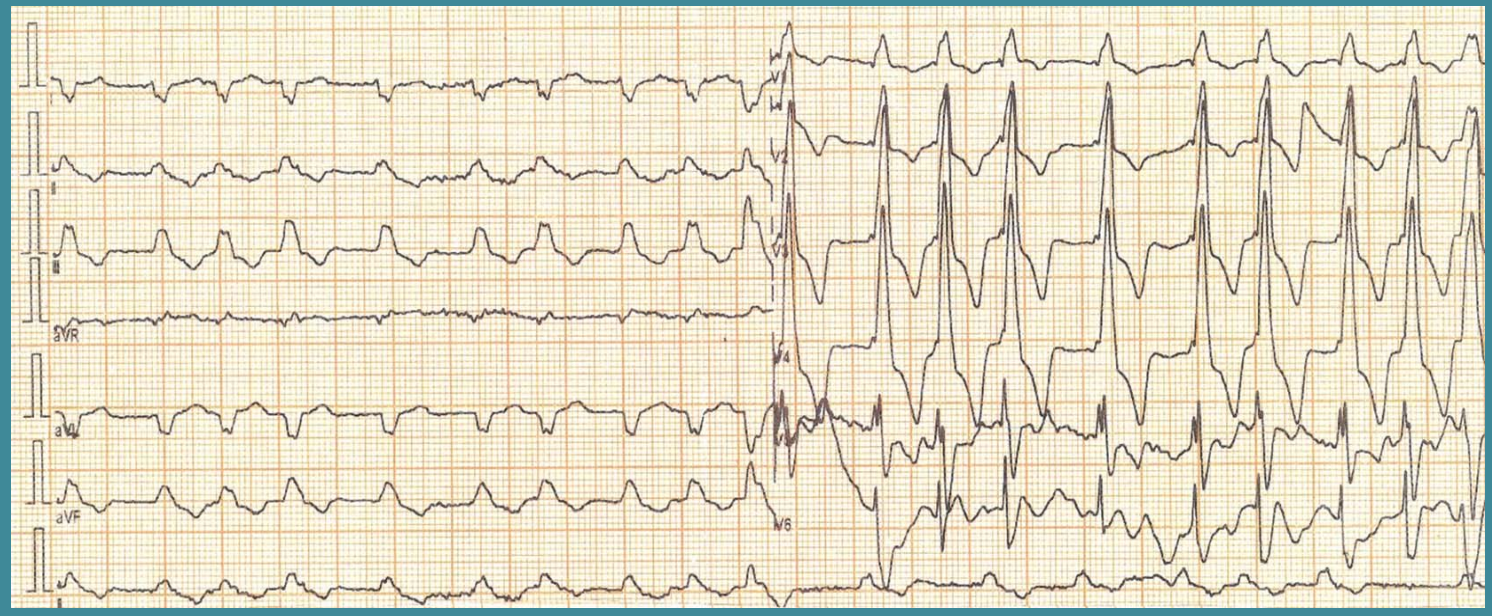

Figure 1. Electrocardiography: atrial fibrillation, right axis deviation with complete right bundle branch block and secondary repolarization changes

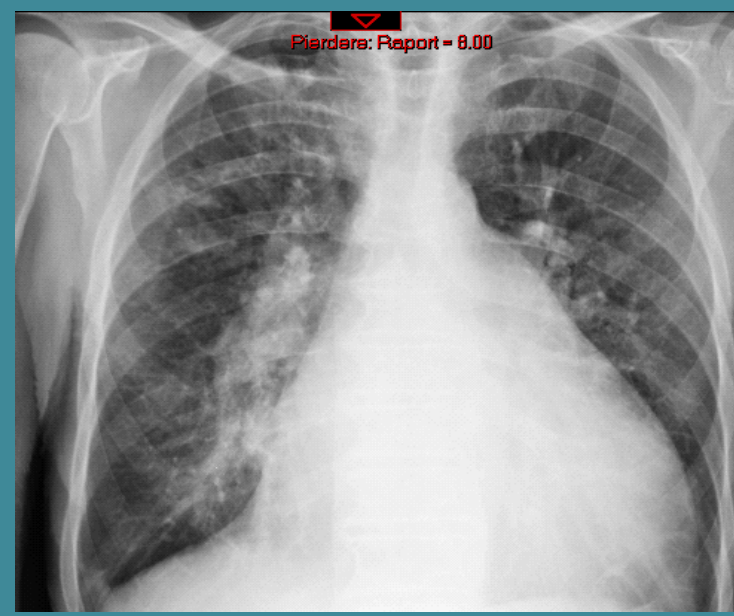

Figure 2. Chest X-ray: cardiomegaly with broad vascular pedicles and bilateral peribronchal cuffing

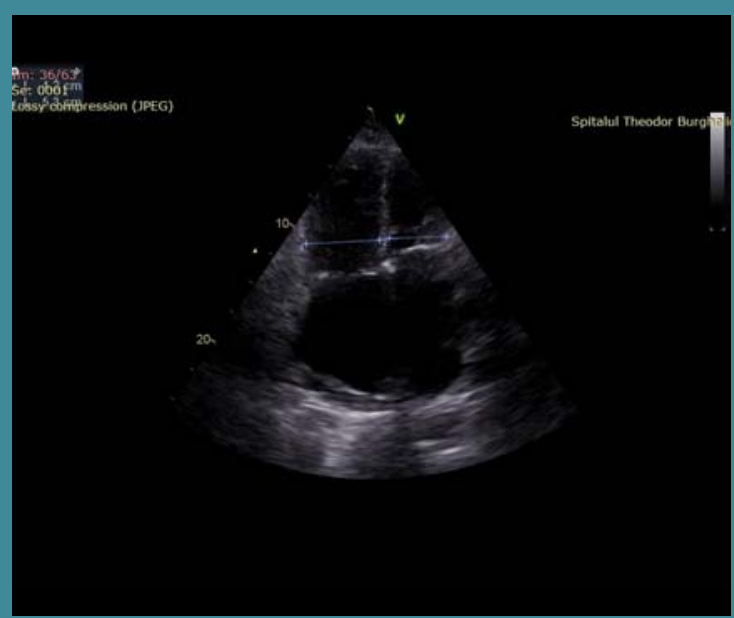

Figure 3. TTE Right ventricle (RV) with a basal diameter superior to the left ventricle basal diameter

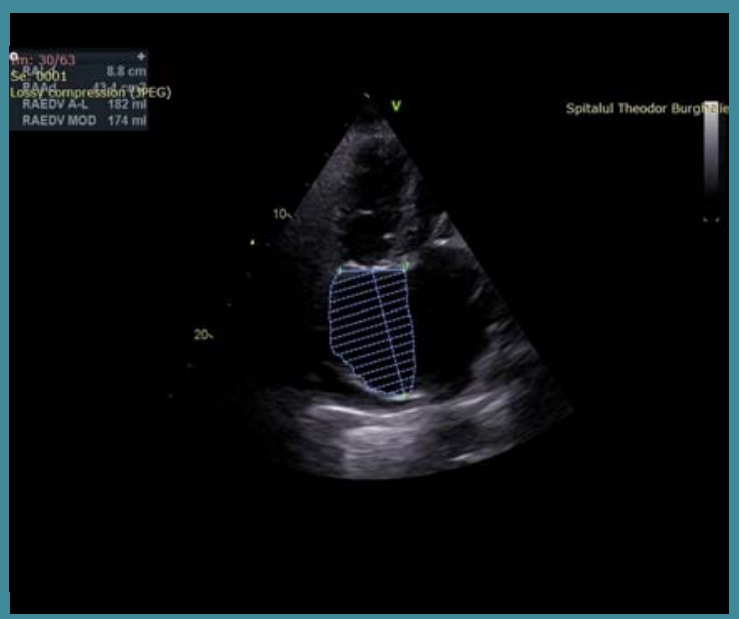

Figure 4. TTE: Dilated RA (43.4 square centimeters

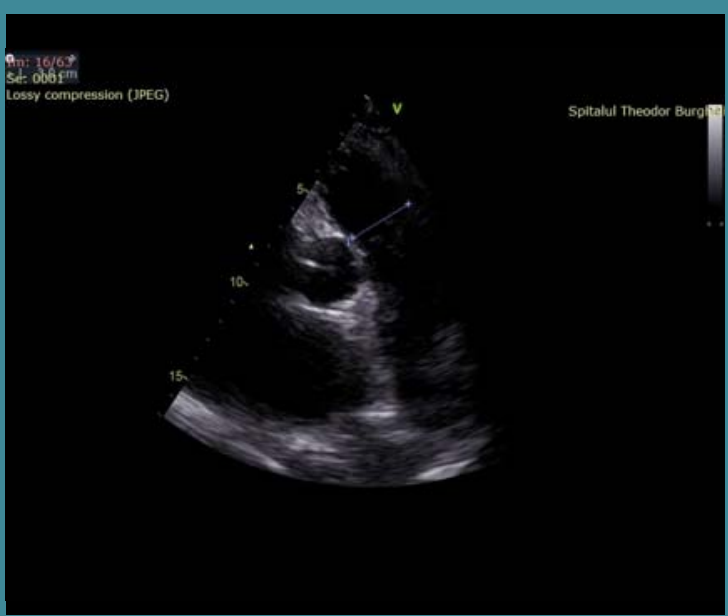

Figure 5. TTE: The pulmonary artery was dilated $(3 \mathrm{~cm})$ 
anti-HCV antibodies, negative HBS antigen, high NT-proBNP and normal TSH levels. Arterial blood gas analysis showed mild respiratory alkalosis (Table 1 ).

An abdominal CT showed hypertrophy of the caudate lobe of the liver with irregular micronodular contour and a heterogeneous structure with imprecise borders in the sixth segment with hypondense signal before and after contrast injection; no abdominal lymphadenopathy, portal vein with a diameter of $1.36 \mathrm{~cm}$ and dilated splenic vein. The CT described also important cardiomegaly by predominant dilation of right cavities and right lateral pericardial effusion (Figure 9).

An upper gastrointestinal endoscopy was also performed, in the context of cirrhosis and imagistic signs of portal hypertension, showing esophageal varices.

Pulmonary function tests did not reveal bronchial obstruction, ruling out COPD.

The positive diagnosis is severe $\mathrm{PH}$, permanent atrial fibrillation, complete right bundle branch block, interstitial pulmonary fibrosis, tuberculosis sequelae, decompensated cord pulmonary, virus $\mathrm{C}$ cirrhosis of the liver complicated with portal hypertension; tumor of the liver; chronic anemia.

At this moment the most important problem was the differential diagnosis of the etiology regarding the severe pulmonary hypertension.

We took into consideration: left ventricular diseases; pulmonary disease (suspected COPD, pulmonary fibrosis, tuberculosis sequelae, obstructive sleep apnea); chronic thromboembolic disease; grown-up congenital heart disease; porto-pulmonary arterial hypertension (PoPH). There are arguments and counterarguments for each of the presumed causes (Table 2).

\section{A thoracic computed tomography} angiography was performed showing the following: suspicion of pulmonary arterial hypertension with dilation of the pulmonary trunk (diameter of $4.1 \mathrm{~cm}$, pulmonary arteries and intrapulmonary branches (Figure 10); bilateral pulmonary interstitial infiltration, fibrous lesions with microcalcifications and bilateral bronchiectasis, cardiomegaly and hypertrophy of the left liver lobe with micronodular surface. There were no signs of emboli in the pulmonary circulation.

We concluded thus that the most probable cause of severe $\mathrm{PH}$ in this case was PoPH.

Unfortunately the patient passed away by right heart failure unresponsive to treatment before a right heart catheterization could take place.

The final diagnoses were: $\mathrm{PoPH}$, decompensated chronic right heart failure, 


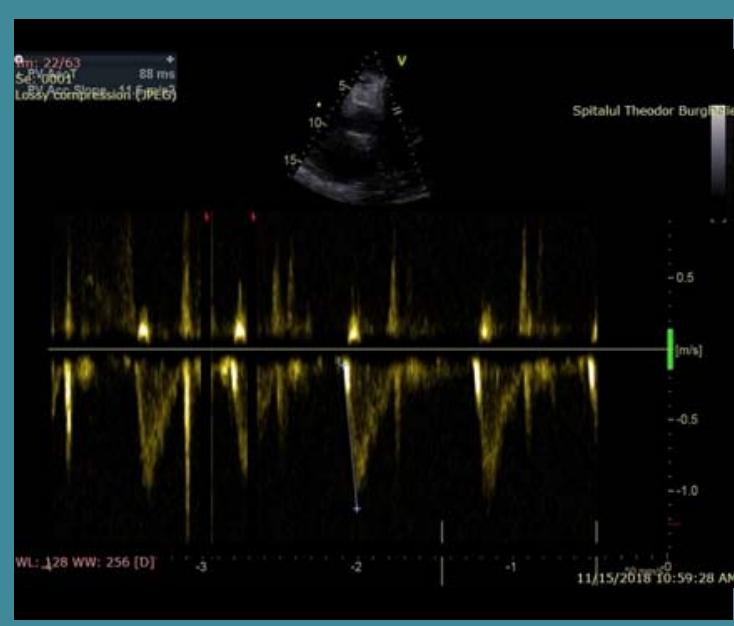

Figure 6. TTE: Pulmonary accelerated time was short (88 $\mathrm{msec})$

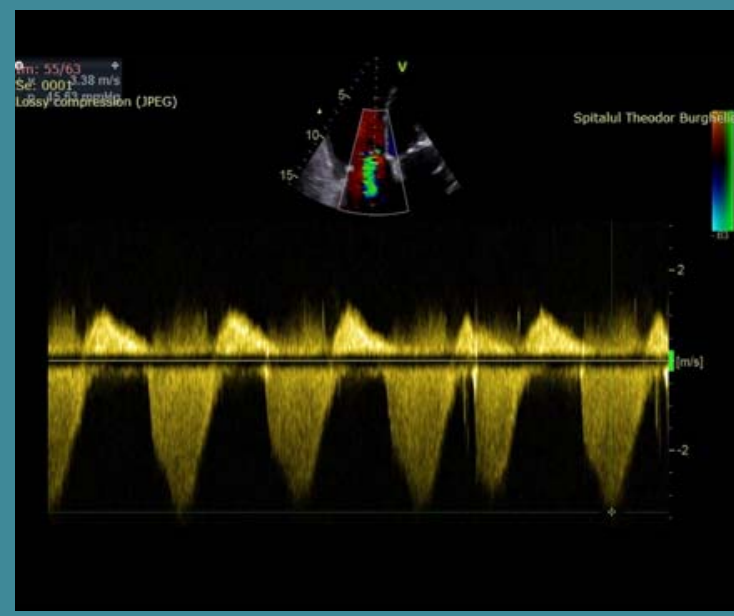

Figure 7. TTE: Tricuspid regurgitation velocity was high $(3.38 \mathrm{~m} / \mathrm{s})$ with a gradient between the RV and right atrium (RA) of $45.63 \mathrm{mmHg}$

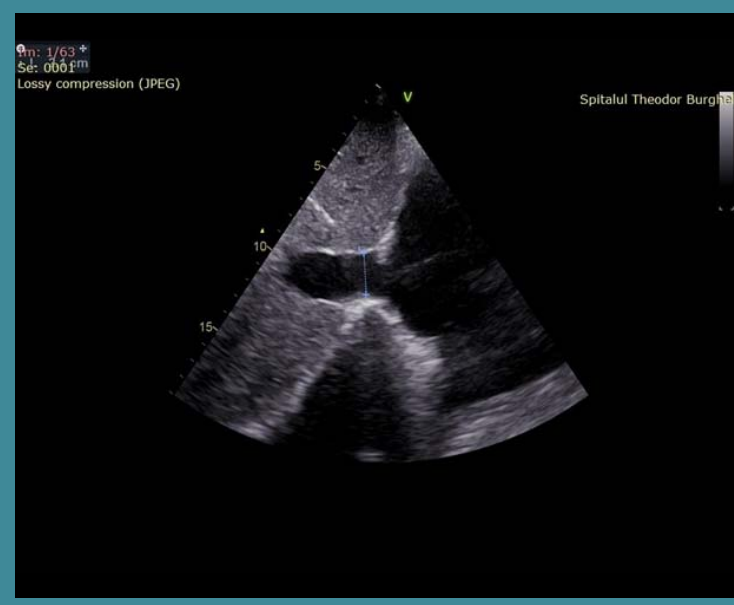

Figure 8. TTE: The vena cava was dilated $(2.1 \mathrm{~cm})$ with insufficient inspiratory collapse (less than 50\%) and RA filling pressures estimated at $15 \mathrm{mmHg}$

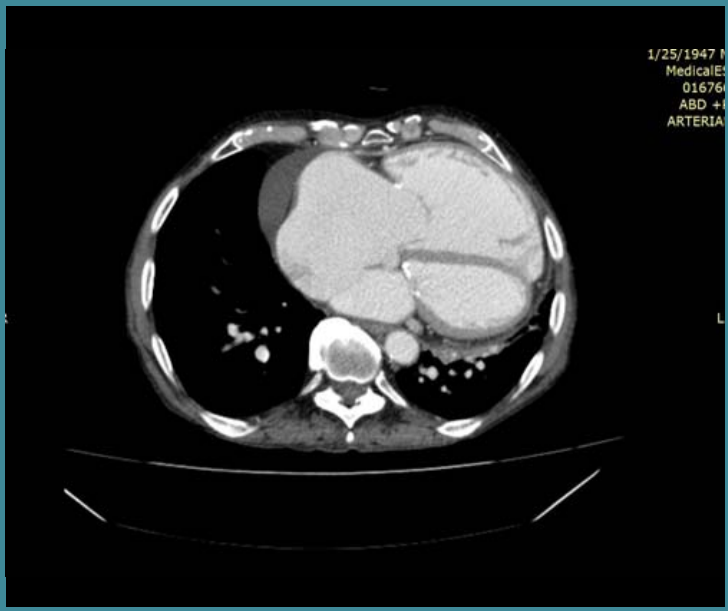

Figure 9. Abdominal CT scan. Cardiomegaly by predominant dilation of straight cavities with right lateral pericardial effusion

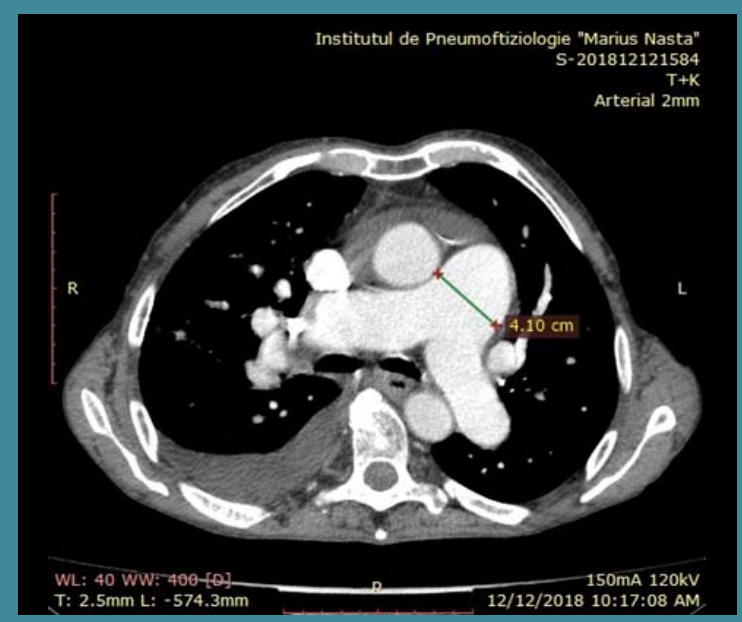

Figure 10. Thoracic CT scan: Dilation of the pulmonary trunk 


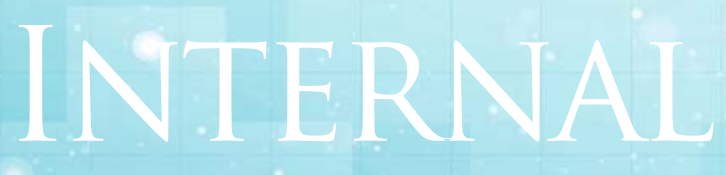

Clinical cases

permanent atrial fibrillation, complete right bundle branch block, pulmonary fibrosis, sequelae of pulmonary tuberculosis, bilateral bronchiectasis, hepatic postnecrotic cirrhosis with hepatic virus $C$ and portal hypertension, suspicion of hepatocellular carcinoma, anemia most probably by mixed mechanism (both iron and folic acid deficiency).

\section{Discussion}

PoPH is as a type of pulmonary arterial hypertension belonging to the first group of etiologies as classified by the ESC 2015 Guidelines for Pulmonary Hypertension. Its definition relies on:

1. Confirmation of the $\mathrm{PH}$ (with the following criteria by right heart catheterization, which is the the gold standard: Mean Pulmonary Artery Pressure (mPAP) > $20 \mathrm{mmHg}$ with Pulmonary Capillary Wedge Pressure $<15 \mathrm{mmHg}$ and Pulmonary Vascular Resistance (PVR) > 3 uW (240 dynes $/ \mathrm{sec} / \mathrm{cm}^{-5}$ ). The criteria of increased vascular resistance is important because it allows the exclusion of those cases in which the increased cardiac output is the sole responsible for the raised pulmonary pressures (by raised pulmonary flow) as those cases are associated with normal pulmonary vascular resistances and do not meet the definition of $\mathrm{PPH}$.
2. Exclusion of alternative etiologies.

3. Confirmation of the $\mathrm{PoH}$ (clinically, imagistically or in rare cases, by hepatic vein catheterization).

It's prevalence ranges between 2 and $16 \%^{\left({ }^{(2)}\right)}$. The risk factors for the occurence of PoPH are female sex, autoimmune hepatitis and primitive biliary cirrhosis but not age or severity of hepatic dysfunction ${ }^{(2)}$. In real life most patients have cirrhosis but PoPH can be associated with other causes of $\mathrm{PoH}$. According to medium pulmonary artery pressure values (mPAP), $\mathrm{PoPH}$ is classified in mild (mPAP 25-35 mmHg), moderate (mPAP $35-44 \mathrm{mmHg}$ ) and severe (mPAP $\geq 45$ $\mathrm{mmHg}$ ).

Anatomical changes in PoPH occur in the precapillary pulmonary arterioles: muscle hypertrophy, endothelial proliferation, adventitial proliferation, plexiform lesions, in situ thrombosis, pulmonary arterioles microaneurysms ${ }^{(6,7)}$.

The exact mechanism of PPH is not completely understood. There are however many theories, some of them regarding the role of the direct passage, through the newly-formed porthosystemic shunts, of either vasoconstrictive substances (which are no longer normally metabolized because of liver dysfunction) or thrombi, some take into account the role of the hyperdinamic circulation while others highlight the importance of systemic inflammation. 


\begin{tabular}{|c|c|c|}
\hline Test & Results & Normal values \\
\hline Hemoglobin & $8.6 \mathrm{~g} / \mathrm{dL}$ & $13+/-2 \mathrm{~g} / \mathrm{dL}$ \\
\hline Leucocytes & $6.210^{\wedge} 3 / \mathrm{ul}$ & $4.5-10.510 \wedge 3 / u l$ \\
\hline CRP & $10.5 \mathrm{mg} / \mathrm{l}$ & $0-5 \mathrm{mg} / \mathrm{L}$ \\
\hline Creatinine & $1.02 \mathrm{mg} / \mathrm{dl}$ & $0.6-1.2 \mathrm{mg} / \mathrm{dL}$ \\
\hline Estimated DFG & $73 \mathrm{ml} / \mathrm{min} / 1.73 \mathrm{~m}^{2}$ & $\begin{array}{l}90-125 \\
\mathrm{ml} / \mathrm{min} / 1.73 \mathrm{~m}^{2}\end{array}$ \\
\hline Sodium & 119.4 mmoli/l & 135-145 mmoli/L \\
\hline Potassium & $4.06 \mathrm{mmoli} / \mathrm{l}$ & 3.5-5 mmoli/L \\
\hline AST & $60.47 \mathrm{UI} / \mathrm{L}$ & 8-40 UI/L \\
\hline ALT & $20 \mathrm{UI} / \mathrm{L}$ & 8-40 UI/L \\
\hline Total bilirubin & $1.36 \mathrm{mg} / \mathrm{dL}$ & $0.1-1 \mathrm{mg} / \mathrm{dL}$ \\
\hline Direct bilirubin & $0.82 \mathrm{mg} / \mathrm{dL}$ & $0-0.3 \mathrm{mg} / \mathrm{dL}$ \\
\hline INR & 1.80 & $0.2-1.2$ \\
\hline Total cholesterol & $55.3 \mathrm{mg} / \mathrm{dL}$ & $<200 \mathrm{mg} / \mathrm{dL}$ \\
\hline HVC antibodies & prezent & absent \\
\hline HBSAg & absent & absent \\
\hline NT-proBNP & 13846 pg/mL & $<300 \mathrm{pg} / \mathrm{ml}$ \\
\hline TSH & $3.608 \mathrm{ulU} / \mathrm{mL}$ & $0.27-4.2 \mathrm{uUl} / \mathrm{mL}$ \\
\hline Arterial blood pH & 7.47 & $7.35-7.45$ \\
\hline Arterial blood pO2 & $85 \mathrm{mmHg}$ & $75-100 \mathrm{mmHg}$ \\
\hline Arterial blood pCO2 & $32 \mathrm{mmHg}$ & $35-45 \mathrm{mmHg}$ \\
\hline $\begin{array}{l}\text { Arterial blood Base } \\
\text { excess }\end{array}$ & $0.4 \mathrm{mmol} / \mathrm{L}$ & $+/-3 \mathrm{mmol} / \mathrm{L}$ \\
\hline
\end{tabular}




\section{INTERNAL MEDICINE}

\section{Clinical cases}

\begin{tabular}{|c|c|c|}
\hline $\begin{array}{c}\text { Presumed etiology } \\
\text { of the PH }\end{array}$ & Arguments & Counterarguments \\
\hline $\begin{array}{c}\text { Causes of left ventricular } \\
\text { dysfunction }\end{array}$ & $\begin{array}{l}\text { History of permanent atrial } \\
\text { fibrillation. } \\
\text { PH possible in left ventricle } \\
\text { diseases irrespective of } \\
\text { ejection fraction. }\end{array}$ & $\begin{array}{l}\text { Non-dilated and non- } \\
\text { hypertrophied left ventricle. } \\
\text { No valvular heart diseases. }\end{array}$ \\
\hline Pulmonary disease & $\begin{array}{l}\text { History of interstitial } \\
\text { pulmonary fibrosis, sequelae } \\
\text { of pulmonary tuberculosis. } \\
\text { Chronic pulmonary diseases } \\
\text { associates most frequently } \\
\text { mild PH }\end{array}$ & $\begin{array}{l}\text { High severity of the } \mathrm{PH}, \\
\text { unappropriated in the } \\
\text { context COPD or interstitial } \\
\text { pulmonary fibrosis. }\end{array}$ \\
\hline $\begin{array}{l}\text { Chronic thromboembolic } \\
\text { disease }\end{array}$ & Patient with low mobility. & $\begin{array}{l}\text { Under anticoagulation for } \\
\text { permanent atrial fibrillation. }\end{array}$ \\
\hline $\begin{array}{l}\text { Porto-pulmonary arterial } \\
\text { hypertension (PoPH) }\end{array}$ & $\begin{array}{l}\text { Virus C cirrhosis of the liver } \\
\text { with suspicion of hepatic } \\
\text { tumor. } \\
\text { Portal hypertension at the } \\
\text { abdominal CT scan. }\end{array}$ & $\begin{array}{l}\text { More often in women, } \\
\text { autoimmune hepatitis and } \\
\text { biliary cirrhosis. }\end{array}$ \\
\hline $\begin{array}{c}\text { Grown-up congenital heart } \\
\text { disease }\end{array}$ & $\begin{array}{l}\text { Sometimes there is an } \\
\text { unexpected discovery of } \\
\text { unknown atrial septal defect } \\
\text { or aberrant pulmonary vein } \\
\text { drainage in adults with } \\
\text { unexplained PH. }\end{array}$ & $\begin{array}{l}\text { No congenital cardiac defect } \\
\text { showed by the TTE. }\end{array}$ \\
\hline
\end{tabular}

Table 2. Differential diagnosis of the etiology of the $\mathrm{PH}$ 
Vasoconstriction of the pulmonary arteries can be induced by high cardiac output increasing parietal shear stress, endotoxins reaching the pulmonary circulation from the gastro-intestinal tract, endotheline 1 acting on $\mathrm{ET}_{\mathrm{A}}$ receptors within the pulmonary arteries, TXA2, IL-6, TNF alpha, serotonine ${ }^{(6,7)}$. There could be also a genetic predisposition.

The occurence of PoPH worsens the patient's outcome. There are some good results with Epoprostenol, lloprost, type 5 phosphodiesterase blockers. The endothelin receptor antagonists cause hepatic cytolysis and are indicated only in patients with mild hepatic impairment. Liver transplantation is contraindicated if MPAP values are more than $35 \mathrm{mmHg}$ and PVR more than 250 dyn sec $\mathrm{cm}^{-5}$. Our patient had also other possible causes of $\mathrm{PH}$ : interstitial pulmonary fibrosis, bronchiectasis, sequele of pulmonary tuberculosis but these causes do not provide severe $\mathrm{PH}$. The lack of left heart disease history and the TTE data do not support the hypothesis of left ventricular dysfunction or congenital heart diseases as causes of $\mathrm{PH}$. The high value of NTproBNP was due to the right heart decompensation. Unfortunately the patient did not have a right heart catheterization.

\section{Learning points}

- Porto-pulmonary hypertension is the association of pulmonary arterial hypertension with portal hypertension, caused by liver disease or an extrahepatic cause, and should be suspected whenever alternative causes of pulmonary hypertension have been excluded.
- Clinical presentation, blood test and transthoracic echocardiography should guide the diagnosis of pulmonary hypertension but invasive measurement by right heart catheterization is mandatory in order to confirm the diagnosis while portal hypertension is usually diagnosed by combining careful history taking, physical examinations, blood and imaging tests and it seldom requires hepatic venous pressure gradient measurement by hepatic venous catheterization.

\section{References:}

1. Benjaminov FS. Portopulmonary hypertension in decompensated cirrhosis with refractory ascites. Gut. 2003;52(9):1355-1362. doi:10.1136/gut.52.9.1355

2. Kawut SM, Krowka MJ, Trotter JF, et al. Clinical risk factors for portopulmonary hypertension. Hepatology. 2008;48(1):196-203. doi:10.1002/hep.22275

3. Galiè N, Humbert M, Vachiery J-L, et al. 2015 ESC/ERS Guidelines for the diagnosis and treatment of pulmonary hypertension: The Joint Task Force for the Diagnosis and Treatment of Pulmonary Hypertension of the European Society of Cardiology (ESC) and the European Respiratory Society (ERS)Endorsed by: Association for European Paediatric and Congenital Cardiology (AEPC), International Society for Heart and Lung Transplantation (ISHLT). Eur HeartJ. 2016;37(1):67-119. doi:10.1093/eurheartj/ehv317 4. Chaouat A, Naeije R, Weitzenblum E. Pulmonary hypertension in COPD. Eur Respir J. 2008;32(5):13711385. doi:10.1183/09031936.00015608

5. Shorr AF, Wainright JL, Cors CS, Lettieri CJ, Nathan SD. Pulmonary hypertension in patients with pulmonary fibrosis awaiting lung transplant. Eur Respir J. 2007;30(4):715-721. doi:10.1183/09031936.00107206

6. Mateo Porres-Aguilar, Jose T Altamirano, Aldo TorreDelgadillo, Michael $R$ Charlton, Andreas Duarte Rojo, Portopulmonary hypertension and hepatopulmonary syndrome: a clinical-oriented overview, Eur Resp Rev, 2012, 21 (125): 223-233)

7. Sonja D. Bartolome, Michael J. Krowka Pulmonary Complications of Intra-abdominal Disease part 13, p 24961508 in Fishman's Pulmonary Diseases and Disorders Fifth Edition McGrawHill, 2015, ISBN: 978-1-25-958912-6 